\title{
Nondestructive Method for Measuring Fruit Ripening of 'La France' Pears Using a Laser Doppler Vibrometer
}

\author{
Hideki Murayama $^{1 *}$, Ichiro Konno ${ }^{1}$, Shoji Terasaki ${ }^{2}$, Ryoichi Yamamoto ${ }^{3}$ and Naoki Sakurai ${ }^{4}$ \\ ${ }^{1}$ Faculty of Agriculture, Yamagata University, Tsuruoka 997-8555, Japan \\ ${ }^{2}$ Corporate R\&D, Matsushita-Kotobuki Electronics Industries, Ltd., Ehime 791-0935, Japan \\ ${ }^{3}$ Laboratory of Biology and Chemistry, Tezukayama College, Nara 631-8585, Japan \\ ${ }^{4}$ Faculty of Integrated Arts \& Sciences, Hiroshima University, Higashi-Hiroshima 739-8521, Japan
}

\begin{abstract}
The elastic index of 'La France' pears was measured during ripening by a laser Doppler vibrometer (LDV). Fruit were harvested thrice during the 1999 season. After harvest, samples of fruit were just allowed to ripen at $20^{\circ} \mathrm{C}$. A portion of optimum-harvested fruit was stored at $1^{\circ} \mathrm{C}$ for 2 weeks or 1,2 or 4 months and transferred to $20^{\circ} \mathrm{C}$ for ripening. The value for the elastic index of early-harvested fruit was $36.4 \times 10^{5} \mathrm{~Hz}^{2} \cdot \mathrm{g}^{2 / 3} \mathrm{just}$ after harvest; the values declined with a function of time. The elastic index of optimum-harvested pear showed a bi-phasic decrease, whereas that of late-harvested fruit exhibited a sharp decrease with a single-phase pattern as the fruit ripened. Storage reduced the elastic index and modified the decreasing pattern. Optimum-harvested fruit that were stored at $1^{\circ} \mathrm{C}$ for 2 weeks showed a slight bi-phasic decrease in the elastic index, whereas fruit stored for 1 or 2 months did not. Fruit stored at $1{ }^{\circ} \mathrm{C}$ for 4 months showed the lowest initial value $\left(4.3 \times 10^{5} \mathrm{~Hz}^{2} \cdot \mathrm{g}^{2 / 3}\right)$ and little decrease. The correlation coefficients between flesh firmness, measured by a conventional probe method and the elastic index, was significantly high, independent of harvest date or storage periods. The only exception was with fruit stored at $1^{\circ} \mathrm{C}$ for 4 months. These results indicate that 'La France' pear fruit exhibit bi-phasic decreases in the elastic index when they were harvested at optimum period and stored for periods up to 2 weeks; furthermore, fruit firmness of 'La France' pears is amenable to analysis by an LDV.
\end{abstract}

Key Words: elastic index, fruit firmness, laser Doppler vibrometer, pear, storage period.

\section{Introduction}

Pears, like avocadoes and kiwifruit, require several days or weeks after harvest to ripen for the development of optimum quality. All characteristics of ripe pear, such as starch and chlorophyll degradation, and the biosynthesis of volatile compounds (Jennings et al., 1964; Shiota, 1990), occur during the ripening process. In addition, fruit that are harvested at an optimum time soften and develop a buttery and juicy texture after several days or within a few weeks after harvest. Many consumers have been unhappy with the purchase of very hard products with little flavor (Bruhn et al., 1991). Providing pears at the correct ripeness should increase consumer satisfaction with the product. Kappel et al. (1995) also showed that firmness was a major attribute that has a strong effect on consumer perception of pear fruit quality; that perceived ripeness increased linearly

Received; October 27, 2004. Accepted; July 29, 2005.

This work was supported in part by the Ministry of Education, Science, Sports and Culture of Japan (Grant-in-Aid for Scientific Research (B) no. 12556006).

* Corresponding author (E-mail: mhideki@tds1.tr.yamagata-u.ac.jp). with the measured firmness. Thus, we tried to measure the flesh firmness nondestructively as the index for the ripeness of pears.

In most pears, such as 'Beurré Bosc' and 'Beurré d'Anjou', the color turns from green to yellow during ripening. When pear fruit reach the edible stage, they can easily be judged from the surface color. However, it is very difficult to determine the exact edible stage of 'La France' pears because there are few external changes, including color that take place after harvest. Nevertheless, 'La France' is the most popular cultivar and accounts for about 70 percent of production in Japan. Therefore, the establishment of a nondestructive method for determining the degree of ripeness of 'La France' fruit was an important goal for this research.

Methods to determine the internal quality of pear fruit without damaging the tissue have been attempted before. Near infrared (NIR) has been extensively utilized for quality evaluation of certain agricultural products (Finney and Morris, 1978; Sverzult et al., 1987). The NIR technique is also useful to determine constituents of fruit, such as sugar (Kawano et al., 1993; Peiris et al., 1998a, b) and organic acid content (Miyamoto et al., 1997). McGlone et al. (1998) reported a significant correlation between soluble solids and fruit firmness 
which suggests that the NIR technique may have an application in the determination of fruit firmness in some cases, but this relationship does not apply in all cases.

Wang and Worthington (1979) measured differences in the optical density $(\triangle \mathrm{OD})$ between 690 and $740 \mathrm{~nm}$ from the surface of intact 'Bartlett' pears during ripening with a single-beam multiwavelength spectrophotometer. They reported that there was a strong correlation between fruit firmness and $\Delta \mathrm{OD}$; they proposed that the $\Delta \mathrm{OD}$ is a useful index for showing the degree of ripeness. It is not known whether this method is effective for pear cultivars other than 'Bartlett'. Cooke (1972) reported that the shear modulus for fruit tissue could theoretically be derived from fruit mass, density, and resonant frequency; he proposed an improved firmness index " $\mathrm{m}^{(2 / 3)} \mathrm{f}_{2}$ " from this theoretical analysis, where " $\mathrm{m}$ " is a fruit mass and ' $\mathrm{f}_{2}$ " is a second resonant frequency. In pears, apples, and tomatoes, a nondestructive method was proposed for measuring fruit firmness by using acoustic vibration (Abott et al., 1968; De Belie et al., 2000; Shmulevich et al., 1996; Stephenson et al., 1973). However, in these studies the sensor for detecting fruit vibration is in contact with the fruit surface. Since fruit vibration is influenced greatly by the mass of the sensor, the results can be unreliable (Muramatsu et al., 1997); thus, they proposed that a laser Doppler vibrometer (LDV) method could be used to measure changes in fruit firmness in a real time scale without direct contact. Terasaki et al. (2001c) reported a strong correlation between the elastic index measured by LDV and flesh firmness in kiwifruit, which supports the theoretical basis for the method (Terasaki et al., 2001a). They also investigated the relationship between cell wall polysaccharides and the elastic index of kiwifuit and indicated that the molecular weight of xyloglucan correlated with the loss in the elastic index (Terasaki et al., 2001b).

The objective of the research reported here was to measure the precise changes in the elastic index of ' $\mathrm{La}$ France' pears during ripening by using an LDV, to investigate the effects of harvest date and storage periods on this index. To assess the reliability of this method, we sought a correlation between it and flesh firmness as determined by a conventional rheometer.

\section{Materials and Methods}

\section{Plant material}

Pear fruit (Pyrus communis L.), 'La France', were harvested in a commercial orchard near Yamagata on Oct. 5, 12 and 19 in 1999. After harvest at each date, 50 fruit were immediately ripened at $20^{\circ} \mathrm{C}$. A portion of fruit (200 fruit) harvested on Oct. 12 was stored at $1{ }^{\circ} \mathrm{C}$ to investigate the effects of storage periods on the elastic index. After 2 weeks or 1, 2 or 4 months, 50 fruit were transferred to $20^{\circ} \mathrm{C}$ to ripen for this purpose.

\section{Rheometer measurement of flesh firmness}

Flesh firmness of one or 2 fruit was measured everyday by using a rheometer (CR-200D, Sun Scientific, Tokyo, Japan) for up to 17 to 34 days. A fruit was cut transversely at the equator into ca. $2 \mathrm{~cm}$ thick slices. The firmness at four sites between peel and core was measured. A conical probe with $60^{\circ}$ apex was driven into the fruit at the rate of $50 \mathrm{~mm} \cdot \mathrm{min}^{-1}$. When the probe reached the depth of $3 \mathrm{~mm}$, the maximum force exerted by the probe was determined.

\section{Elastic index measurement by $L D V$}

The elastic indices of five fruit were measured daily during ripening by using the LDV method (Terasaki et al., 2001c) until fruit reached an overripe stage. Briefly, the fruit was weighed and then placed on the stage of the vibration generator (512-A, EMIC, Osaka, Japan) measurement system. Each fruit was subjected to sinusoidal excitation, ranging from $0 \mathrm{~Hz}$ to $3000 \mathrm{~Hz}$. The vibration signal at the top of the fruit (X out), measured by the LDV (LV-1300, ONO SOKKI, Yokohama, Japan), was analyzed by Fast Fourier Transformation (FFT) (CF-5210, ONO SOKKI). Vibration at the generator level was monitored by an accelerometer (NP3110 , ONO SOKKI). This signal level (X in) was also input to the FFT analyzer which computed the frequency response of the fruit (Xout/Xin). The elastic index was calculated with an equation, " $\mathrm{m}^{(2 / 3)} \mathrm{f}_{2}$ " (Cooke, 1972; Terasaki et al. 2001c). The elastic index of another batch of fruit was measured daily by LDV, and these fruit were simultaneously analyzed for flesh firmness by a rheometer.

\section{Results and Discussion}

\section{Changes in the elastic index during ripening}

Changes in the elastic index by LDV for five individual fruit that were harvested on Oct. 12 and immediately ripened at $20^{\circ} \mathrm{C}$ (Fig. 1) indicated that the initial elastic index of 'La France' pear fruit at harvest was between $28 \times 10^{5}$ and $33 \times 10^{5} \mathrm{~Hz}^{2} \cdot \mathrm{g}^{2 / 3}$. Then the elastic index

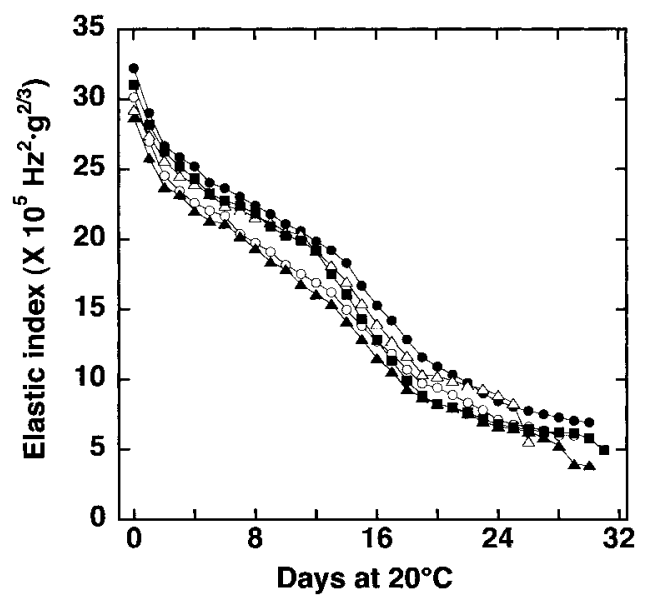

Fig. 1. Changes in the elastic index of 'La France' pears shown by using LDV during ripening $(n=5)$. Fruit were harvested on Oct. 12 . 
rapidly decreased for the first two days of ripening, followed by a gradual decrease until day 14 . The elastic index again rapidly decreased from day 14 to day 19 at $20^{\circ} \mathrm{C}$. Terasaki et al. $(2001 \mathrm{c})$ had reported that the elastic index of kiwifruit decreased rapidly during ripening. To our knowledge, the bi-phasic pattern of changes in the elastic index of ripening fruit was first observed in this study.

\section{Changes in the elastic index during ripening in fruit harvested at different times}

Most winter pears do not ripen optimally at an ambient temperature until after exposure to cold for a critical period of time (Chen et al., 1993); each cultivar has a specific chilling requirement (Chen et al., 1982). The 'La France' pears can ripen without chilling, but they ripen over an extended period of time. The length of time for fruit to reach good quality was from day 22 to day 32 for fruit harvested on Oct. 5, from day 21 to day 30 for fruit harvested on Oct. 12 , and from day 14 to day 23 for fruit harvested on Oct. 19.

The average elastic index for fruit harvested on Oct. 5 was $36.4 \times 10^{5} \mathrm{~Hz}^{2} \cdot \mathrm{g}^{2 / 3}$. The values gradually and steadily declined (single phase) during ripening (Fig. 2). The averaged elastic index of fruit harvested on Oct. 12 also showed the clear bi-phasic decrease, whereas that of fruit harvested on Oct. 19 was $31.3 \times 10^{5} \mathrm{~Hz}^{2} \cdot \mathrm{g}^{2 / 3}$; it decreased rapidly as fruit ripened, and exhibited a single phase. There have been numerous studies on the effects of harvest date on ripening (Chen and Mellenthin, 1981; Elgar et al., 1997; Murayama et al., 1998). The basis for the bi-phasic decrease in elastic index in fruit harvested on Oct. 12 needs further biochemical and genetic studies.

On fruit harvested on Oct. 5, Oct. 12 and Oct. 19 which were allowed to ripen at an ambient temperature $\left(20^{\circ} \mathrm{C}\right)$, the flesh firmness declined after an initial lag

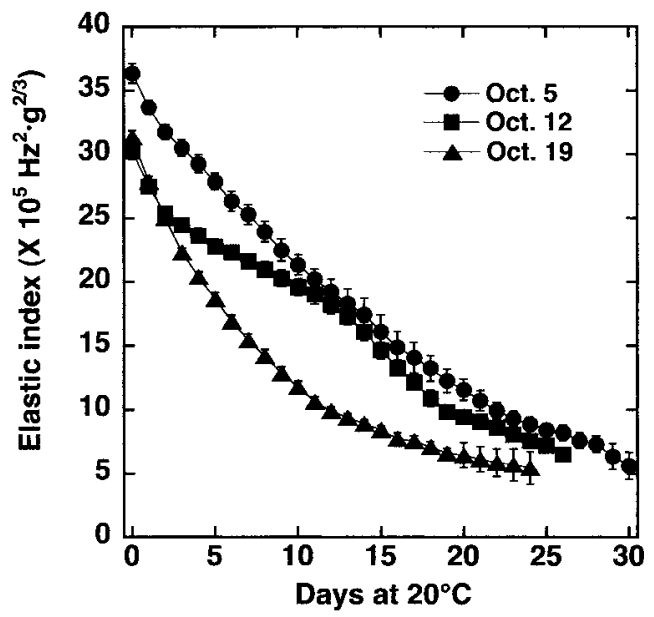

Fig. 2. Changes in the elastic index as determined by the LDV of ' $\mathrm{La}$ France' pears harvested at different times. Fruit were harvested on Oct. 5, Oct. 12 or Oct. 19. Values are means $\pm \operatorname{SE}(n=5)$. time (data not shown). The lag was shorter in fruit harvested on Oct. 19 than in fruit harvested on Oct. 5 or 12. The decline in the LDV value, however, always commenced immediately after harvest or when transferred to $20^{\circ} \mathrm{C}$ after $1^{\circ} \mathrm{C}$ storage. Mechanisms related to this difference are not clear.

\section{Changes in the elastic index during ripening in stored at different periods}

The times when fruit quality was highest were from day 15 to day 17 for fruit stored for 2 weeks, from day 10 to day 15 for that for 1 month, and from day 9 to day 14 for that for 2 months. Fruit stored for 4 months never developed a buttery and juicy texture; they deteriorated and became inedible.

Changes in the elastic index of fruit that were harvested on Oct. 12, stored for 2 weeks, 1, 2 or 4 months, and ripened at $20^{\circ} \mathrm{C}$ (Fig. 3) reveal that after storage at $1^{\circ} \mathrm{C}$, the initial elastic index steadily decreased from $30.3 \times 10^{5} \mathrm{~Hz}^{2} \cdot \mathrm{g}^{2 / 3}$ at harvest to $4.3 \times 10^{5} \mathrm{~Hz}^{2} \cdot \mathrm{g}^{2 / 3}$ after a 4-month storage. The elastic index of fruit stored at $1^{\circ} \mathrm{C}$ for 2 weeks showed a slight bi-phasic pattern, whereas that of fruit stored for 1 or 2 months failed to reveal any evidence for a bi-phasic decrease but a steady decrease as fruit ripened. The elastic index at the beginning of the ripening period after 1 or 2 months was significantly less than that after 2 weeks storage. It appears that the initial decrease in the elastic index bi-phasic pattern was negated during 1 or 2 month storage at $1^{\circ} \mathrm{C}$. Fruit stored at $1^{\circ} \mathrm{C}$ for 4 months showed almost no decline in elastic index even after transfer to $20^{\circ} \mathrm{C}$.

\section{Relationship between flesh firmness and the elastic index in fruit}

The relationships between rheometer and LDV firmness values for fruit harvested at different times (Fig.

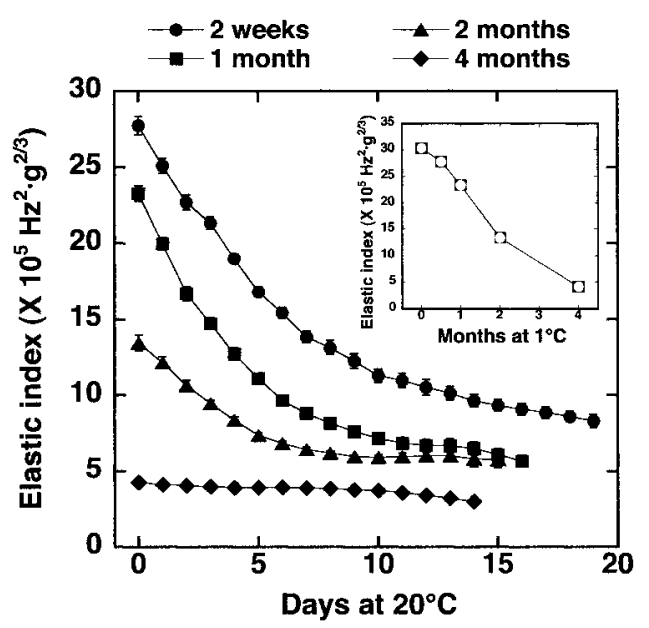

Fig. 3. Changes in elastic index shown by using LDV of 'La France' pears stored for different periods. Fruit were harvested on Oct. 12 and stored for 2 weeks, 1 month, 2 month or 4 month. Values are means $\pm \mathrm{SE}(\mathrm{n}=5)$. The inset graph shows changes in elastic index during storage at $1^{\circ} \mathrm{C}$. 
4) show that flesh firmness did not significantly change in fruit with elastic index values of more than $20 \times 10^{5} \mathrm{~Hz}^{2} \cdot \mathrm{g}^{2 / 3}$. Hence, the elastic index data less than $20 \times 10^{5} \mathrm{~Hz}^{2} \cdot \mathrm{g}^{2 / 3}$ were used for regression analysis. Correlation coefficients were significant at the $1 \%$ level, irrespective of harvest date. For the firm fruit with an index greater than $50 \times 10^{4} \mathrm{~N} \cdot \mathrm{m}^{-2}$, a poor correlation existed between LDV and rheometer data, which suggests that the LDV yields a more precise estimate on the degree of firmness than dose the rheometer reading.

The relationships between flesh firmness and the
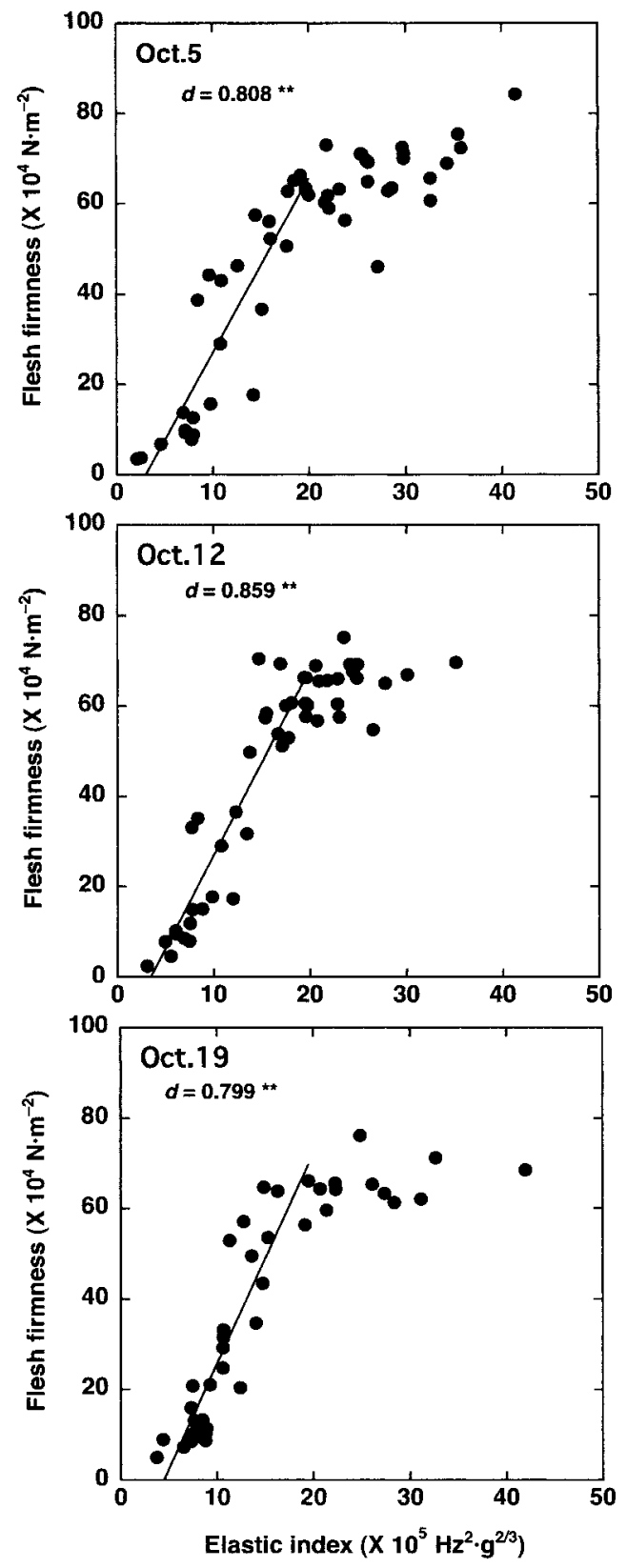

Fig. 4. Plot distribution showing the relationship between LDV elastic index and rheometer firmness of 'La France' pears harvested on Oct. 5 (A), Oct. 12 (B) or Oct. 19 (C). Statistical significance is given at $P<0.01(* *)$. elastic index of fruit stored for different periods (Fig. 5) reveal that the elastic index values of less than $20 \times 10^{5} \mathrm{~Hz}^{2} \cdot \mathrm{g}^{2 / 3}$ for regression analysis yields $r$ values that were significant at the $1 \%$ level, irrespective of storage periods. However, the $r$ values for fruit stored for 2 and 4 weeks were higher than for those stored 2 or 4 months; fruit stored for 2 weeks with the flesh firmness more than $60 \times 10^{4} \mathrm{~N} \cdot \mathrm{m}^{-2}$ exhibited a poor correlation between LDV and rheometer data. LDV may determine the degree of firmness of hard fruit more precisely than a rheometer (Fig. 4). We conclude, therefore, that LDV may determine the degree of firmness of firm fruit more precisely than a rheometer.

The correlation coefficients between flesh firmness and the elastic index was poor for fruit stored for 4 months at $1{ }^{\circ} \mathrm{C}$ (Fig. 5). In pears, it is known that an abnormal softening pattern occurs when fruit is transferred to $20^{\circ} \mathrm{C}$ after prolonged storage (Mellenthin and Wang, 1976; Wang et al., 1985). When Murayama et al. (2002) transferred 'La France' pears to $20^{\circ} \mathrm{C}$ after 5 months at $1{ }^{\circ} \mathrm{C}$, they did not develop the desirable buttery, juicy texture, just as our results disclosed.

Irrespective of harvest date, the optimum time for eating was when the LDV elastic index and rheometer firmness of 'La France' pears were approximately $9 \times 10^{5} \mathrm{~Hz}^{2} \cdot \mathrm{g}^{2 / 3}$ and $15 \times 10^{4} \mathrm{~N} \cdot \mathrm{m}^{-2}$, respectively. These results indicate that flesh firmness of pears can be measured nondestructively and precisely by an LDV, if the fruit are immediately ripened without storage or ripened after storage up to 2 weeks. However, in 'La France' pears stored for more than 1 month, the LDV elastic index decreased significantly, based on storage period. These values decreased to about $7 \times 10^{5} \mathrm{~Hz}^{2} \cdot \mathrm{g}^{2 / 3}$ for fruit stored for 1 month and $6 \times 10^{5} \mathrm{~Hz}^{2} \cdot \mathrm{g}^{2 / 3}$ when stored for 2 months, so that it is difficult to judge eating quality from LDV elastic index readings alone. The reason for which the storage period affected the LDV elastic index is not clear, but needs additional investigations to elucidate it.

In conclusion, the LDV measurements clearly demonstrate that the 'La France' pear fruit exhibit a postharvest bi-phasic pattern as the elastic index declines, provided the fruit are harvested during the optimum maturation period and stored for a short time. Such a unique characteristic decrease in elasticity of fruit was detected only after the non-destructive, precise, continual measuring system was developed. The correlations between flesh firmness and the elastic index are highly significant, regardless of harvest date when the initial flesh firmness is below $50 \times 10^{4} \mathrm{~N} \cdot \mathrm{m}^{-2}$; they are also highly significant independent of storage periods with the exception of fruit stored for 4 months at $1{ }^{\circ} \mathrm{C}$.

\section{Acknowledgement}

We thank Prof. D. J. Nevins of University of California, Davis for his critical reading of the manuscript. 

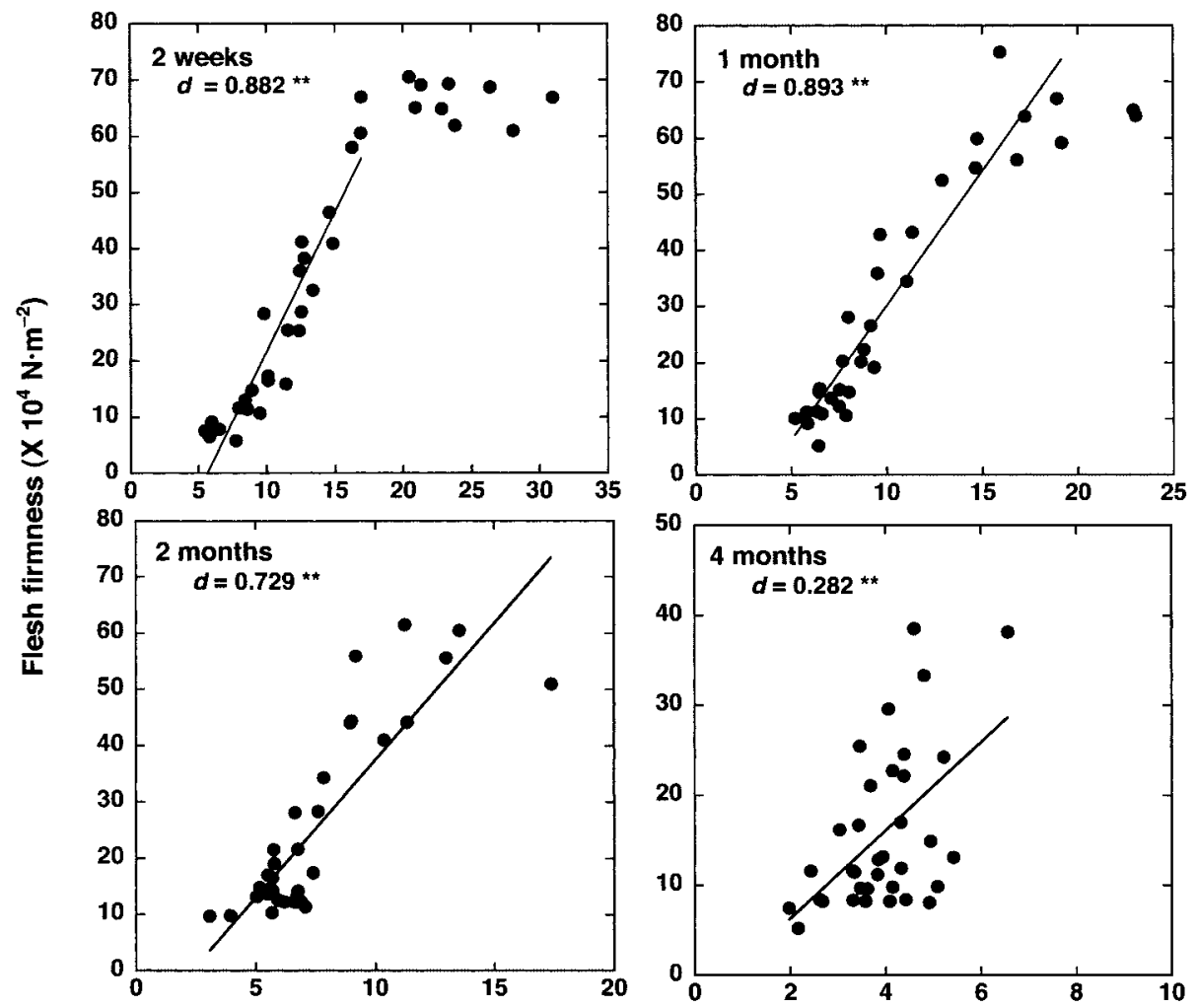

Elastic index $\left(\times 10^{5} \mathrm{~Hz}^{2} \cdot \mathrm{g}^{2 / 3}\right)$

Fig. 5. Plot distribution showing the relationship between LDV elastic index and rheometer firmness of 'La France' pears harvested on Oct. 12 and stored for 2 weeks (A), 1 month (B), 2 months (C) or 4 months (D). Statistical significance is given at $P<0.01(* *)$.

\section{Literature Cited}

Abott, J. A., G. S. Bachmann, N. F. Childers, J. V. Fitzgerald and K. F. Matusik. 1968. Sonic techniques for measuring texture of fruits and vegetables. Food Technol. 22: 635646.

Bruhn, C. M., N. Feldman, C. Garlitz, J. Harwood, E. Ivans, M. Marshall, A. Riley, D. Thurber and E. Williamson. 1991. Consumer perceptions of quality: Apricots, cantaloupes, peaches, pears, strawberries, and tomatoes. J. Food Quality. 14: 187-195.

Chen, P. M. and W. M. Mellenthin. 1981. Effects of harvest date on ripening capacity and postharvest life of 'd'Anjou' pears. J. Amer. Soc. Hort. Sci. 106: 38-42.

Chen, P. M., D. G. Richardson and W. M. Mellenthin. 1982. Differences in biochemical composition between 'Beurre d'Anjou' and 'Bosc' pears during fruit development and storage. J. Amer. Soc. Hort. Sci. 107: 807-812.

Chen, P. M., D. M. Varga and E. A. Mielke. 1993. Ripening behavior of 'Columbia' and 'Gebhard' strains of red 'd'Anjou' pears after cold storage. J. Amer. Soc. Hort. Sci. 118: 81-85.

Cooke, J. R. 1972. An interpretation of the resonant behavior of intact fruit and vegetables. Transaction of the ASAE 15: 1075-1080.

De Belie, N., S. Schotte, J. Lammertyn, B. Nicolai and J. De
Baerdemaeker. 2000. Firmness changes of pear fruit before and after harvest with the acoustic impulse response technique. J. Agric. Engng. Res. 77: 183-191.

Elgar, H. J., C. B. Watkins, S. H. Murray and F. A. Gunson. 1997. Quality of 'Buerre Bosc' and 'Doyenne du Comice' pears in relation to harvest date and storage period. Postharvest Biol. Technol. 10: 29-37.

Finney, E. E. and K. H. Morris. 1978. Determination of moisture in corn kernels by near-infrared transmittance measurements. Transaction of the ASAE 21: 581-584.

Jennings, W. G., R. K. Creveling and D. E. Heinz. 1964. Volatile esters of Bartlett pear. IV. Esters of trans-2, cis-4-decadienoic acid. J. Food Sci. 29: 730-734.

Kappel, F., R. Fisher-Fleming and E. J. Hogue. 1995. Ideal pear sensory attributes and fruit characteristics. Hort Science 30: 988-993.

Kawano, S., H. Watanabe and M. Iwamoto. 1993. Nondestructive determination of sugar content in Satsuma mandarin using near infrared (NIR) transmittance. J. Japan. Soc. Hort. Sci. 62: 465-470.

McGlone, V. A., R. B. Jordan and S. Kawano. 1998. Firmness, dry-matter and soluble solids assessment of postharvest kiwifruit by NIR spectroscopy. Postharvest Biol. Technol. 13: 131-141.

Mellenthin, W. M. and C. Y. Wang. 1976. Preharvest temperatures in relation to postharvest quality of 
'd'Anjou' pears. J. Amer. Soc. Hort. Sci. 101: 302-305. Miyamoto, K., M. Kawauchi and T. Fukuda. 1997. Classification of high acid fruits by PLS using the near infrared transmittance (NIT) spectra of intact Satsuma mandarins. J. Near Infrared Spec. 6: 267-271.

Muramatsu, N., N. Sakurai, R. Wada, R. Yamamoto, K. Tanaka, Y. Ishikawa-Takano and D. J. Nevins. 1997. Critical comparison of an accelerometer and a laser Doppler vibrometer for measuring fruit firmness. HortTechnology 7: 434-438.

Murayama, H., T. Katsumata, O. Horiuchi and T. Fukushima. 2002. Relationship between fruit softening and cell wall polysaccharides in pears after different storage periods. Postharvest Biol. Technol. 26: 15-21.

Murayama, H., T. Takahashi, R. Honda and T. Fukushima T., 1998. Cell wall changes in pear fruit softening on and off the tree. Postharvest Biol. Technol. 14: 143-149.

Peiris, K. H. S., G. G. Dull, R. G. Leffler and S. J. Kays. 1998a. Near-infrared spectrometric method for nondestructive determination of soluble solids content of peaches. J. Amer. Soc. Hort. Sci. 123: 898-905.

Peiris, K. H. S., G. G. Dull, R. G. Leffler and S. J. Kays. 1998b. Near-infrared (NIR) spectrometric technique for nondestructive determination of soluble solids content in processing tomatoes. J. Amer. Soc. Hort. Sci. 123: 10891093.

Shiota, H. 1990. Changes in the volatile composition of La France pear during maturation. J. Sci. Food. Agric. 52: 421-429.

Shmulevich, I., N. Galili and D. Rosebfeld. 1996. Detection of fruit firmness by frequency analysis. Transaction of the ASAE 39: 1047-1055.

Stephenson, K. Q., R. K. Byler and M. A. Wittman. 1973. Vibrational response properties as sorting criteria for tomatoes. Transaction of the ASAE 16, 258-265.

Sverzult, C. B., L. R. Verma and A. D. French. 1987. Sugarcane analysis using near infrared spectroscopy. Transaction of the ASAE 30: 255-258.

Terasaki, S., N. Sakurai, N. Wada, T. Yamanishi, R. Yamamoto and D. J. Nevins. 2001a. Analysis of the vibration mode of apple tissue using electronic speckle pattern interferometry. Transaction of the ASAE 44: 1697-1705.

Terasaki, S., N. Sakurai, R. Yamamoto N. Wada and D. J. Nevins. 2001b. Changes in cell wall polysaccharides of kiwifruit and the visco-elastic properties detected by a laser Doppler method. J. Japan. Soc. Hort. Sci. 70: 572 580.

Terasaki, S., N. Wada, N. Sakurai, N. Muramatsu, R. Yamamoto and D. J. Nevins. 2001c. Nondestructive measurement of kiwifruit ripeness using a laser Doppler vibrometer. Transaction of the ASAE 44: 81-87.

Wang, C. Y., C. E. Sams and K. C. Gross. 1985. Ethylene, ACC, soluble polyuronide, and cell wall noncellulosic neutral sugar content in 'Eldorado' pears during cold storage and ripening. J. Amer. Soc. Hort. Sci. 117: 600 606.

Wang, C. Y. and J. T. Worthigton. 1979. A nondestructive method for measuring ripeness and detecting core breakdown in 'Bartlett' pears. J. Amer. Soc. Hort. Sci. 104: 629-631.

\author{
レーザードップラー法によるセイヨウナシ ‘ラ・フランス’ 果実熟度の非破壊測定

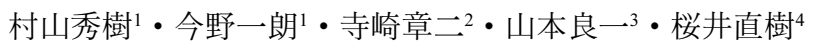 \\ ${ }^{1}$ 山形大学農学部 997-8555 鶴岡市若葉町 \\ 2松下寿電子工業株式会社 791-0395 愛媛県温泉郡川内町 \\ 3帝塚山大学短期大学部 631-8585 奈良市学園南 \\ 4広島大学総合科学部 739-8521 東広島市鏡山
}

レーザードップラー振動計（LDV）を用いて，セイヨ ウナシ ‘ラ・フランス’ 果実の追熟中に弾性率を測定し た。果実は 1999 年に 3 回採取し，それぞれ収穫後ただ ちに $20^{\circ} \mathrm{C} て ゙$ 追熟を行った. 収穫適期に採取した果実の一 部は $1{ }^{\circ} \mathrm{C}$ で貯蔵し，2 週間，1 か月，2 か月あるいは 4 か 月後 $20^{\circ} \mathrm{C}$ に移し追熟を行った。 早期収穫果に扎いて, 収 穫時の弾性率は $36.4 \times 10^{5} \mathrm{~Hz}^{2} \cdot \mathrm{g}^{2 / 3}$ であり，追熟に伴い低 下した。適期収穫果では，弾性率が 2 段階の減少パタ一 ンを示した。他方，晚期収穫果では，追熟に伴い弾性率 が指数関数的に低下した。貯蔵中に弾性率は低下し，貯 蔵期間によって弾性率の減少パターンが変化した。すな わち, 適期に収穫し $1^{\circ} \mathrm{C} て ゙ 2$ 週間貯蔵した果実では, 弾
性率が 2 段階の減少パターン示した. 1 か月間あるいは 2 か月間貯蔵した果実では, 追熟中に弾性率が指数関数的 に低下した。他方，4 か月間貯蔵した果実では，追熟開 始時の弾性率が最も小さく $\left(4.3 \times 10^{5} \mathrm{~Hz}^{2} \cdot \mathrm{g}^{2 / 3}\right)$, 追熟中の 変化も小さかった．収穫日あるいは貯蔵期間の違いにか かわらず，レオメーターで測定した果実硬度と弾性率と の間には高い相関関係が認められた。ただし，4 か月間 貯蔵した果実での相関は低かった。これらの結果より, セイヨウナシ ‘ラ・フランス’ では，収穫適期に採取し 低温貯蔵期間が短い果実では，追熟中の弾性率が 2 段階 の減少パターン示すこと，また，LDV による果実硬度の 非破壊測定が可能であることが判明した。 